\title{
About Ecology of Acer Campestre L. (Aceraceae) on North-Eastern Limit of the Range
}

\author{
Yulia N. Utorova ${ }^{1}$, Anatoliy A. Khapugin ${ }^{1,2, *}$, Tatyana B. Silaeva ${ }^{1}$ \\ ${ }^{1}$ Biological Faculty, Mordovian State University, Saransk, 430005, Republic of Mordovia, Russian Federation \\ ${ }^{2}$ Mordovian State Nature Reserve, Pushta, 431230, Republic of Mordovia, Temnikov district, Russian Federation \\ *Corresponding Author: hapugin88@yandex.ru
}

Copyright (C) 2014 Horizon Research Publishing All rights reserved.

\begin{abstract}
Composition of the flora that is accompanying to the Acer campestre in the north-eastern border of the range has been investigated. Its analysis has been carried out according to relation of plant species to the some environmental factors. Ecological groups have been specified in relation to the lighting / shading, in relation to water. Ecological-coenotical analysis has been carried out. Species of accompanying flora have been assigned to the life-form groups according to the Raunkiaer's life-form classification. It has been shown that Acer campestre represented by undersized individuals on the north-eastern border of the range. Shade-tolerant species of vascular plants are dominated within accompanying flora.
\end{abstract}

Keywords Acer campestre, Red Data Book, accompanying flora, range, Republic of Mordovia

\section{Introduction}

Effects of anthropogenic factors influence on the living nature are degradation and restructuring of natural ecosystems, violation of existing coenotical relations between its components, increasing the proportion of synanthropic plant communities. At the level of flora, this process is expressed primarily in the degradation of native component in result of the gradual extinction of stenotopic species and species that are near the range border [1-4]. Population-based investigations of plants play an important role in understanding of the biological diversity. They are the starting point for the organization of sustainable using of plant resources, for conducting of the nature protection actions including the creation of new Protection Areas (PAs) [5]. Investigations of population status for species that are near the range border are especially relevant [6-8].

Field maple (Acer campestre L.) is Euro-Minor-Asian species which is distributed in most of Europe from $\mathrm{N}$. England, S. Sweden and C. Russia southwards, but rare in the Mediterranean region [9] (Fig. 1). This species is becoming rare in the north-eastern part of the range. In the Ryzan' region Acer campestre is observed a frequently in the south-west and west part of region and it is more rare to the east $[10,11]$. In 2011, species has been removed from the main list of the regional Red Data Book [12]. Also Acer campestre is rare in the Penza region. It is known in the western part of region (Vadinsk district, Bashmakovo district, Zemetchino district, Kamenka district, Pachelma district, Belinskiy district, Tamalino district). [13,14]. Field maple is included in the Red Data Book of the Republic of Mordovia. It has the category 3 (rare species) [15]. In the Republic of Mordovia Acer campestre is known from Insar district, Kadoshkino district, Kovylkino district, Kochkurovo district, Ruzaevka district and urban district Saransk [5].

It is aestisilvae deciduous tree up to 15 (20) m. Left-sided spectrum of Acer campestre population is characterized for this species on the north-eastern limit of the range [14], height of the most individuals (70.8\%) is within $1 \mathrm{~m} \mathrm{[16]}$. Leaves are opposite, 3 (5)-lobate; three upper blades often have one large tooth on each side; blades and teeth are smooth-margin and blunted at apex. Flowering period is from late April to early May. Inflorescence is paniculate, multiflorous. Flowers are greenish-yellow, with massive nectareous discs. Fruit is samarium up to $3-4 \mathrm{~cm}$ long and diverging at an obtuse angle. It propagated by seeds and vegetatively [17-19].

At Central European alluvial hardwood forests Acer campestre L. plays a dominant role within group of tree species. It is one of species that are typical of zonal European forests $[20,21]$. According to the life-strategy model of Grime [22] with modifications [23] field maple at Central Europe is ranked into the group of stress-tolerant ruderals (S-R).

\section{Materials and Methods}

At the present paper we carried out gradient analysis of the flora that is accompanying to the Acer campestre. Investigations have been carried out in deciduous forest that located in the valley of Issa river on the most north-eastern border of range (Republic of Mordovia), 53.925137 $\mathrm{N}$, $44.377158^{\circ} \mathrm{E}$. Investigations of this population have been carried out during 2011-2012 seasons. 


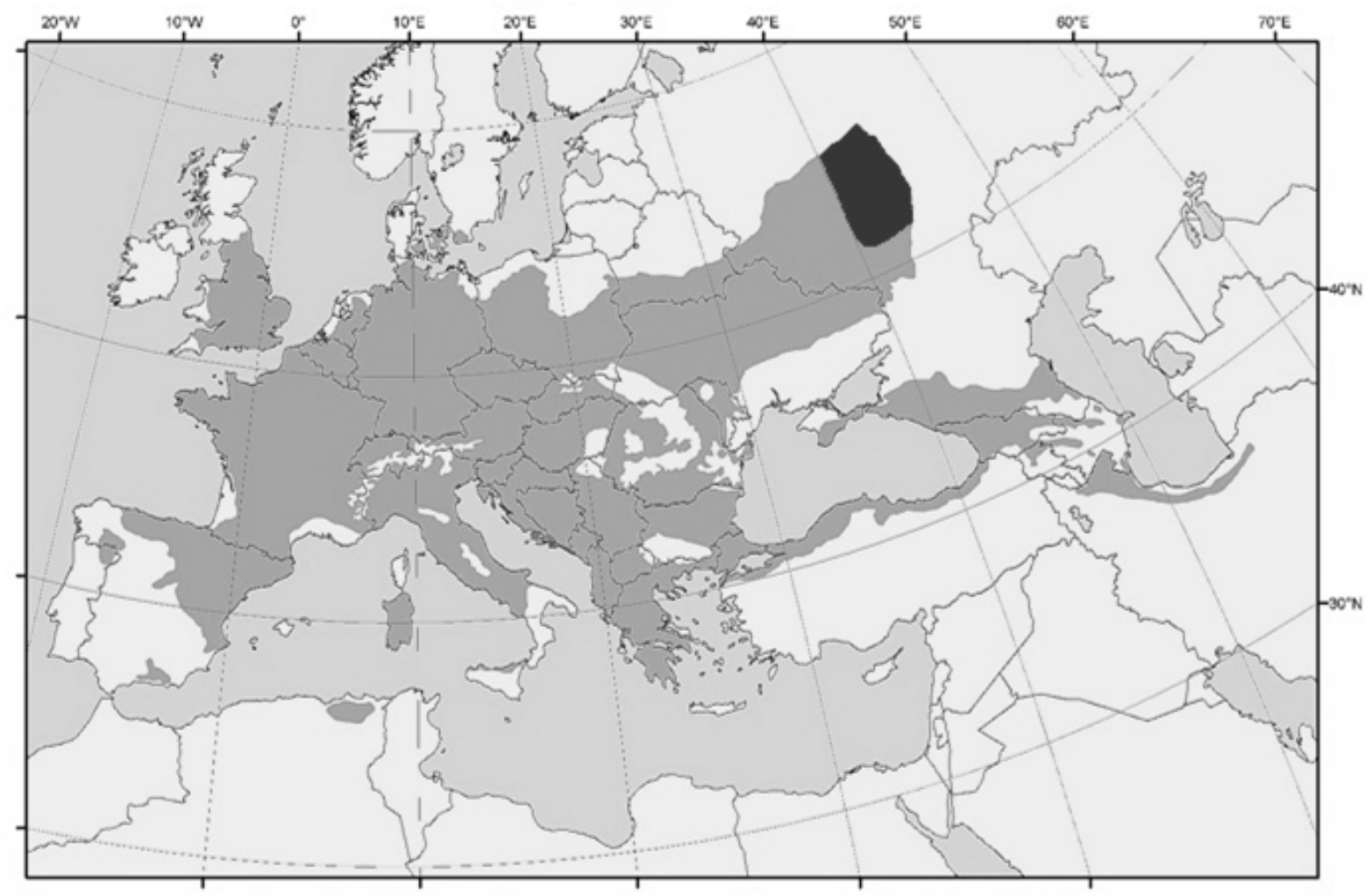

Figure 1. Natural range of the Acer campestre L. Its north-western part (Republic of Mordovia, Ryazan' region, Penza region) is marked in dark-gray (Map with modifications is from web site of European Forest Genetic Resources Programme: www.euforgen.org)

Acer campestre population was sampled using 2 randomly located $100 \times 100(1 \mathrm{ha}) \mathrm{m}$ plots. Three study units of $10 \times 10$ (0.01 ha) $\mathrm{m}$ were established within each of these plots.

Species composition of flora, which is accompanying field maple, has been recorded within each study unit. Counting of all trees in the canopy layer has been conducted within each study unit to determine of stand formula of this plant community with participation of Acer campestre. Stand formula has been determined as mean percent of individuals of stand in the canopy layer per 100 square meters (area of one study unit).

Ecological conditions, that are typical to habitats with Acer campestre, have been evaluated using the data on the ecological preferences of vascular plant species which are grow with field maple together.

Biomorphological analysis of the flora, that is accompanying the field maple, has been carried out with separation of life forms according to the Raunkiaer's life-form classification [24]. This life-form classification is the most informative to achieve our aim, compared with some other studies [25-28].

Distribution of plant species of the accompanying flora on the ecological groups in relation to water has been carried out according to the classification of A. P. Shennikov [29] with separation of main groups (hydrophytes, hygrophytes, mesophytes, xerophytes) and intermediate groups (hygromesophytes, mesohygrophytes, xeromesophytes, mesoxerophytes).

Ecological scales proposed by H. Ellenberg [30,31], E.
Landolt [32], and D. N. Tsyganov [33] have been used in distribution of plant species of the accompanying flora on the ecological groups in relation to the lighting / shading.

Ecological-coenotical characteristics for each plant species that was registered on study units has been determined using literature on the flora of the Republic of Mordovia [5] and the flora of Central Russia [34] and our personal observations.

\section{Results and Discussion}

The flora accompanying Acer campestre includes 56 species of vascular plants from 48 genera and 32 families. Below we present a list of them.

Family 1. Dryopteridaceae

1. Dryopteris filix-mas L.

Family 2. Alismataceae

2. Alisma plantago-aquatica L.

Family 3. Gramineae

3. Festuca altissima All.

4. Poa nemoralis L.

5. Dactylis glomerata L.

6. Melica nutans L.

7. Milium effusum L.

Family 4. Cyperaceae

8. Carex digitata L.

9. Carex pilosa Scop.

10. Carex leporina L. 
Family 5. Liliaceae

11. Polygonatum multiflorum L.

12. Convallaria majalis L.

Family 6. Orchidaceae

13. Platanthera bifolia L.

Family 7. Betulaceae

14. Corylus avellana L.

Family 8. Fagaceae

15. Quercus robur L.

Family 9. Urticaceae

16. Urtica dioica L.

Family 10. Aristolochiaceae

17. Asarum europaeum L.

Family 11. Polygonaceae

18. Polygonum hydropiper L.

19. P. convolvulus L.

Family 12. Caryophyllaceae

20. Stellaria nemorum L.

21. S. graminea L.

22. S. holostea L.

Family 13. Ranunculaceae

23. Anemone ranunculoides L.

24. Ranunculus acris L.

Family 14. Fumariaceae

25. Corydalis solida (L.) Clairv.

Family 15. Rosaceae

26. Rubus saxatilis L.

27. Sorbus aucuparia L.

28. Fragaria vesca L.

29. Rosa cinnamomea L.

30. Malus sylvestris (L.) Mill.

Family 16. Leguminosae (Fabaceae)

31. Lathyrus vernus L.

32. Vicia sylvatica L.

Family 17. Euphorbiaceae

33. Mercurialis perennis L.

Family 18. Celastraceae

34. Euonymus verrucosa L.

Family 19. Aceraceae

35. Acer campestre L.

36. A. platanoides L.

Family 20. Balsaminaceae

37. Impatiens noli-tangere L.

Family 21. Tiliaceae

38. Tilia cordata Mill.

Family 22. Violaceae

39. Viola mirabilis L.

Family 23. Lythraceae

40. Lythrum salicaria L.

Family 24. Umbelliferae (Apiaceae)

41. Aegopodium podagraria L.

42. Angelica sylvestris L.

Family 25. Primulaceae

43. Lysimachia nummularia L.

Family 26. Oleaceae

44. Fraxinus excelsior L.

Family 27. Labiatae (Lamiaceae)
45. Betonica officinalis L.

46. Glechoma hederacea L.

Family 28. Scrophulariaceae

47. Scrophularia nodosa L.

48. Melampyrum nemorosum L.

Family 29. Rubiaceae

49. Galium odoratum L.

Family 30. Caprifoliaceae

50. Lonicera xylosteum L.

Family 31. Campanulaceae

51. Campanula patula L.

52. C. trachelium L.

Family 32. Compositae (Asteraceae)

53. Arctium minus L.

54. A. tomentosum Mill.

55. Taraxacum officinale L.

56. Heiracium umbellatum L. s. 1.

Canopy layer in the investigated plant community is composed by Tilia cordata Mill. and Acer platanoides L., by single individuals of Quercus robur L. и Fraxinus excelsior L. Stand formula of this plant community may be designated as $60 \%$ Tilia cordata and $40 \%$ Acer platanoides + Quercus robur + Fraxinus excelsior. Understory layer is presented by Malus sylvestris (L.) Mill., Sorbus aucuparia L., Acer campestre, Corylus avellana L. Shrub layer includes Euonymus verrucosa Scop., Lonicera xylosteum L. and regrowth of Acer platanoides and Tilia cordata. 45 species form the ground cover. Of these, Carex pilosa is dominant.

Table 1 includes data on the distribution of plant species of accompanying flora on ecological groups in relation of plants to water.

Table 1. Ecological groups on the basis of relation of plants to water in plant community with Acer campestre

\begin{tabular}{|c|c|c|}
\hline Ecological group & Number of species & \% total number of species \\
\hline Mesophytes & 33 & 59.0 \\
\hline Hygromesophytes & 7 & 12.5 \\
\hline Xeromesophytes & 6 & 10.7 \\
\hline Mesohygrophytes & 5 & 8.9 \\
\hline Hygrophytes & 4 & 7.1 \\
\hline Hydrophytes & 1 & 1.8 \\
\hline Total & 56 & 100.0 \\
\hline
\end{tabular}

Table 1 show that the investigated plant community with Acer campestre has been formed in conditions of sufficient moisture. It is typical to the deciduous forests located in the valleys of rivers.

High proportion of mesophytes (33 species or $59.0 \%$ of the all accompanying flora) is shown. Among them, there are Acer platanoides, Lathyrus vernus, Stellaria graminea, etc. Other groups include much less species: from 7 (hygromesophytes) to 1 (hydrophyte - Alisma plantago-aquatica) representatives.

Table 2 includes data on the distribution of plant species of 
the accompanying flora on the ecological groups in relation of plants to the lighting / shading.

Table 2. Ecological groups of plants in relation to the lighting / shading in plant community with Acer campestre

\begin{tabular}{|c|c|c|}
\hline Ecological group & Number of species & $\%$ total number of species \\
\hline Shade-tolerant & 37 & 66.1 \\
\hline Light-demanding & 16 & 28.6 \\
\hline Shade-demanding & 3 & 5.3 \\
\hline Total & 56 & 100.0 \\
\hline
\end{tabular}

In relation to the lighting / shading, as seen from Table 2, shade-tolerant plants dominated in the investigated plant community (37 species). Among them, there are Vicia sylvatica, Milium effusum, Lonicera xylosteum, etc. It indicates the creation of a significant shading here. However, significant number of light-demanding species $(28.6 \%)$ of the accompanying flora exists in this plant community.

An ecological-coenotical characteristic of the flora, which is accompanying Acer campestre, is presented in Table 3 with distributing of plant species on several ecological-coenotical groups.

Table 3. Ecological-coenotical characteristics of the flora which is accompanying Acer campestre in the investigated plant community

\begin{tabular}{|c|c|c|}
\hline Ecological-cenotical group & $\begin{array}{c}\text { Number of } \\
\text { species }\end{array}$ & $\begin{array}{c}\text { \% total number of } \\
\text { species }\end{array}$ \\
\hline Eurytopic-forest & 26 & 46.4 \\
\hline Nemoral-forest & 9 & 16.1 \\
\hline Meadow & 6 & 10.7 \\
\hline Weed & 5 & 8.9 \\
\hline Forest-meadow & 4 & 7.1 \\
\hline Littoral-aquatic & 2 & 3.6 \\
\hline Meadow-steppe & 1 & 1.8 \\
\hline Meadow and edge of the forest & 1 & 1.8 \\
\hline Forest swamp & 1 & 1.8 \\
\hline Weed-forest & 1 & 1.8 \\
\hline Total & 56 & 100.0 \\
\hline
\end{tabular}

Species of the eurytopic-forest ecological-coenotical group are predominate (26 species or $46.4 \%$ ) in the accompanying flora of investigated plant community with Acer campestre. Among them, there are Asarum europaeum, Galium odoratum, Platanthera bifolia, etc. Nemoral-forest group of plants is located on the second place. These plants are typical primarily for broad-leaved forests: Festuca altissima, Carex pilosa, Corydalis solida, etc. Other groups include from 6 (meadow) to 1 (meadow-steppe, meadow and edge of the forest, swamp-forest, weed-forest) species. Thus, within the investigated plant community the Acer campestre population coexists in conjunction with typical nemoral-forest species which are typical for deciduous forests of the Republic of Mordovia.

Among groups according to the Raunkiaer's life-form classification [24], as seen from Table 4, hemicryptophytes group includes half of species of the accompanying flora (28 species). Intensive vegetative reproduction is typical for these plant species (Betonica officinalis L., Dactylis glomerata L., Carex leporina L., etc.). Phanerophytes that determine the environmental conditions in forest communities (Tilia cordata, Acer platanoides, etc.) are located on the second place (9 species) in the ratio of life-form groups (16.1\%). Other groups include from 7 (cryptophytes) to 2 (nanophanerophytes) species.

Table 4. The ratio of life-form groups of plants species of accompanying flora according to the Raunkiaer's life-form classification [24]

\begin{tabular}{|c|c|c|}
\hline Life form & $\begin{array}{c}\text { Number of } \\
\text { species }\end{array}$ & $\begin{array}{c}\% \text { total number of } \\
\text { species }\end{array}$ \\
\hline Hemicryptophytes & 28 & 50.0 \\
\hline Phanerophytes & 9 & 16.1 \\
\hline Cryptophytes & 7 & 12.5 \\
\hline Therophytes & 4 & 7.1 \\
\hline $\begin{array}{c}\text { Hemicryptophytes and } \\
\text { geophytes }\end{array}$ & 3 & 5.3 \\
\hline $\begin{array}{c}\text { Chamaephytes } \\
\text { Nanophanerophytes }\end{array}$ & 3 & 5.3 \\
\hline Total & 56 & 3.6 \\
\hline
\end{tabular}

Acer campestre individuals are represented primarily by the nanophanerophyte life-form in the investigated plant community [16], despite the description of this species as a tree (phanerophyte) in many publications $[5,17,35$,etc.]. This life-form is typical for field maple on the range borders. Based on the results of our studies we may conclude that here Acer campestre is also ranked into the group of stress-tolerant ruderals (R-S) according to the Grimian model [22] and Brzeziecki \& Kienast investigation [23] as it is noted for forests of Central Europe. Signs of human impact including tree felling were noted within the investigated plant community. The monitoring on status of this coenopopulation requires. Area with oak forest on the valley side of Issa river as well as the plot of its floodplain in neighborhood of Adashevo village (Kadoshkino district of the Republic of Mordovia) should be recommended for the protection in the status of Protected Area of regional value.

\section{Conclusion}

Acer campestre is the rare species on the north-eastern range border which grows in the understory and shrub layers of deciduous forests. In the investigated plant community field maple is located in the lime-maple forest in sufficient moisture conditions. Significant shading is noted in the investigated plant community. However it allows coexisting 
large number of the light-demanding plant species here (28.6\% species of the accompanying flora). Under these conditions Acer campestre coexists in this community with the nemoral-forest species that are typical for the broad-leaved forests of the Republic of Mordovia. Groups hemicryptophytes and geophytes are include most species of the accompanying flora of ground layer. Among them, Carex pilosa is dominant species. On the most north-eastern range border Acer campestre is presented by individuals of nanophanerophyte life-form, unlike those in the central part of range where its individuals are trees up to $15 \mathrm{~m}$. The investigated Acer campestre population in Kadoshkino district of the Republic of Mordovia is offered for protection in the status of nature sanctuary of regional value.

\section{Acknowledgements}

We thank to anonymous reviewers for valuable comments on the manuscript.

\section{REFERENCES}

[1] A. M. Gilyarov. Imaginary and real problems of biodiversity, Advances of modern biology, Vol.116, No4, 493-506, 1996 [In Russian].

[2] R. I. Burda. Criteria for adaptation of regional flora to influence of human, In: Study of biological diversity by methods of comparative floristics: Proceeding of the IV workshop on the comparative floristics, House of Saint Petersburg State University, 260-272, 1998 [In Russian].

[3] Botanic Gardens Conservation International. A Review of International Conventions Which Affect the Work of Botanic Gardens. BGCNews, Vol.3(2), Botanic Gardens Conservation International, U.K, 29-55, 1999.

[4] Global Strategy for Plant Conservation, Montreal (Canada); Richmond (U.K.), 2003.

[5] T. B. Silaeva, I. V. Kiryukhin, G. G. Chugunov, V. K. Levin, S. R. Mayorov, E. V. Pismarkina, A. M. Ageeva, E. V. Vargot. Vascular plants of the Republic of Mordovia (synopsis of flora), Publisher of the Mordovian State University, Saransk, 2010 [In Russian].

[6] A. A. Chistyakova. Distribution and population structure of Dentaria quinquefolia Bieb. in the Penza region, Proceeding of the Penza State Pedagogical University, No5(9), 29-32, 2007 [In Russian].

[7] M. V. Markov. Geography and ecology of Lunaria rediviva, Vestnik of the Tver State University, Geography and Geoecology Series, Vol.1(9), 68-89, 2011 [In Russian].

[8] M. V. Puzyr'kina, T. B. Silaeva, D. S. Labutin. Status of population of Scutellaria supina L. (Lamiaceae) in the Republic of Mordovia, Proceeding of the Penza State Pedagogical University, No25, 154-159, 2011 [In Russian].

[9] S. M. Walters. Aceraceae, In: Fl. Europaea / T. G. Tutin \& V.
H. Heywood (Eds.), Cambridge University Press, 2: 237-239, 1968.

[10] E. G. Guschina. Distribution of field maple and tatarian maple in the Ryazan' region, Bulletin of Moscow Society of Naturalists, Biological series, Vol.86, No6, 136-139, 1981 [In Russian].

[11] M. V. Kazakova. Flora of the Ryazan' region, Publisher Russkoe slovo, Ryazan, 2004 [In Russian]

[12] Red Data Book of the Ryazan region, House "Golos gubernii", Ryazan, 2011 [In Russian].

[13] V. M. Vasyukov. Plants species of the Penza region, Publisher of the Penza State University, Penza, 2004 [In Russian].

[14] M. V. Pecherina, N. A. Leonova. Distribution of Acer campestre L. in the Penza region, Forest-steppe of the Eastern Europe: structure, dynamics and protection: Materials of the International conference, Publisher of the Penza State University, Penza, 241-242, 2013 [In Russian].

[15] N. A. Barmin. Field maple, In: Red Data Book of the Republic of Mordovia. Vol.1: Rare species of plants, lichens and fungi / T. B. Silaeva (Ed.), Publisher of the Mordovian State University, Saransk, 157, 2003 [In Russian].

[16] Yu. N. Utorova, A. A. Khapugin. About cenopopulation of field maple (Acer campestre L.) in Kadoshkino district of the Republic of Mordovia, Sbornik nauchnyh trudov SWorld. Proceedings of the international scientific-practical conference «Scientific researches and their practical application. Modern state and ways of development '2012», Vol.31, No3, 10-11, 2012 [In Russian].

[17] S. Ya. Sokolov, O. A. Svyazeva, V. A. Kubli. Ranges of trees and bushes of USSR: In 3 vol., Vol.3, Nauka, Leningrad, 1986 [In Russian].

[18] I. A. Gubanov, K. V. Kiseleva, V. S. Novikov, V. N. Tikhomirov. Illustrated keys to the plants of Middle Russia. Vol.2: Angiosperms (dicotyledons: separate-petaled), KMK Scientific Press Ltd., Moscow, 2003 [In Russian].

[19] K. V. Kiseleva, S. R. Mayorov, V. S. Novikov. Flora of Central Russia: Atlas-determinant, Publisher "Fiton+", Moscow, 2010 [In Russian].

[20] R. Carbiener, A. Schnitzler. Evolution of major pattern models and processes of alluvial forest of the Rhine in the rift valley (France/Germany), Vegetatio, Vol.88, 115-129, 1990.

[21] D. Janik, D. Adam, T. Vrska, L. Hort, P. Unar, K. Kral, P. Samonil, D. Horal. Field maple and hornbeam populations along a 4-m elevation gradient in an alluvial forest, Eur J Forest Res, Vol.130, 197-208, 2011.

[22] J. P. Grime. Plant strategies and vegetational processes, Wiley, New York, 1979.

[23] B. Brzeziecki, F. Kienast. Classifying the life-history strategies of trees on the basis of the Grimian model, For Ecol Manage, Vol.69, 167-187, 1994.

[24] C. Raunkiaer. The life forms of plant and statistical plant geography, Clarendon Press, Oxford, 1934.

[25] V. N. Golubev. About study of life forms of plants for phytocoenology aims, Botanical Journal, Vol.53, No8, 
1085-1093, 1968 [In Russian].

[26] V. N. Golubev. Principles of construction and content of a linear system of angiosperms life forms, Bulletin of Moscow Society of Naturalists, Biological series, Vol.77, No6, 72-80, 1972 [In Russian].

[27] I. G. Serebryakov. Ecological morphology of plants and their study, Vysshaya shkola, Moscow, 1962 [In Russian].

[28] I. G. Serebryakov. Life forms of vascular plants, In: Field geobotanics, Nauka, Moscow-Leningrad, Vol.3, 146-205, 1964 [In Russian].

[29] A. P. Shennikov. Ecology of plants, Sovetskaya nauka, Moscow, 1950 [In Russian].

[30] H. Ellenberg. Zeigerwerte der Gefasspflanzen Mitteleuropas, Goltze, Gottingen, 1974 [In German].
[31] H. Ellenberg. Vegetation Mitteleuropas mit den Alpen in okologischer, dynamischer und historischer Sicht, 5, Aufl. Ulmer, Stuttgart, 1996 [In German].

[32] E. Landolt. Okologische Zeigerwerte zur Schweizer Flora, Veroff. Geobot. Inst. ETH, Zurich, H.64. S. 1-208, 1977 [In German].

[33] D. N. Tsyganov. Phytoindication of ecological regimes in the conifer-broadleaf forest subzone, Nauka, Moscow, 1983 [In Rusian].

[34] P. F. Maevsky. Flora of the middle zone of the European part of Russia, Vol.10, KMK Scientific Press Ltd., Moscow, 2006 [In Russian].

[35] P. V. Kulikov. Synopsis of flora of the Chelyabinsk region (vascular plants), Publisher "Geotur", Ekaterinburg-Miass, 2005 [In Russian]. 